\title{
Cognitive \& Pragmatic Approach to the Phraseological Intensifiers of Political Discourse
}

\author{
Nadejda Zubareva ${ }^{1} \&$ Iroda Siddikova ${ }^{2}$ \\ PhD Candidate ${ }^{1}$. DSc, Professor ${ }^{2}$. Comparative Linguistics Department \\ National University of Uzbekistan named after Mirzo Ulugbek. \\ Contact: zubarevan@yahoo.com
}

\begin{abstract}
The present paper reports on a study that aims to explore the cognitive and pragmatic potential of leveraging phraseological intensifiers in English political discourse. The authors argue that the phraseological intensifiers of political discourse could not be discussed without any contribution to the extra-linguistic context. Therefore, the present study works with a cognitive linguistic explanation of the phraseological intensifiers used by English politicians and journalists as well as performed pragmatic impact that aimed to foster the relevant conceptualization process. The suggestion of phraseological intensifiers depends on context linguistic meaning in the employed by the authors cognitive-pragmatic paradigm. This paper also denotes a wide range of relative to intensity categories, which should be distinguished from it. Such an analysis allows the authors to account for the wide distribution of intensifiers and their co-occurrence with categories that do not encode degree variables. The results of the study show that phraseological intensifiers significantly outperformed in the degree of pragmatic suggestion in political discourse and made use of them in a more appropriate way.
\end{abstract}

Keywords: Intensification; Phraseological Intensifiers; Cognitive; Pragmatic; Political discourse.

\section{Introduction}

In the modern society of the rapid spread of information and digitalization, growing communication worldwide arises the question of mutual intercultural understanding. Growing digitalization requests prompt reactions to global processes and their instant conceptualization by humans. Therefore, intercultural communication takes a special place while talking about foreign policy. It is very important to reach mutual understanding in the dialog between participants with diverse not only personal but cultural backgrounds such as English, Russian, and Uzbek.

Political discourse, like any other type of discourse, should be understood as a type of social interaction where "actors co-construct meaning in the contexts of social situations according to socio-cultural practices” (Johansson 2006).

Political discourse is a vague term. According to Bell "we are all political beings in our everyday life" (Bell 1975). However, in the present context the focus is on the political discourse delivered by politicians while conducting their professional activities as well as political articles in mass media. "Politics cannot be conducted without language" (Chilton and Schaffner 1997).

"Politics as we know it would not only be indescribable without language, it would be impossible. Emerging nations could not declare independence, leaders instruct partisans, citizens protest war, or courts sentence criminals. Neither could we criticize, plead, promise,

(c) AesthetixMS 2021. This Open Access article is published under a Creative Commons Attribution Non-Commercial 4.0 International License (http://creativecommons.org/licenses/by-nc/4.o/), which permits non-commercial re-use, distribution, and reproduction in any medium, provided the original work is properly cited. For citation use the DOI. For commercial re-use, please contact editor@rupkatha.com. 
argue, exhort, demand, negotiate, bargain, compromise, counsel, brief, debrief, advice nor consent. To imagine politics without these actions would be to imagine no recognize politics at all" (Ornatowski 2017).

In its broadest terms, political discourse refers to the written, spoken, or non-verbal language which is used by politicians. The politicians use prosodic features of voice such as speed, volume, intonation and stress to help get their message across and make it memorable for the audience and argue for the need when looking at political discourse, to consider these features (Pridham 2005).

Politicians and journalists also use different expressive and figurative linguistic units to produce persuasive and suggestive impact on audience. The exaggeration and intensification are very often taking place in persuasive speeches of politicians and journalist' articles. Constantly striking for public opinion political figures as well as journalists have the interest to agitate the audience for particular actions. Therefore, they often resort to the use of collocations with redefined meaning phraseological units (PU henceforth). PU refer to the expressive means of language. Political actors often underline high points of the speech not only by PU with figurative, expressive, emotional characters but also intensifying in their core.

Political speech and texts are well-planned actions, demanding long and meticulous preparation as politicians not only aspire to inform the audience about some aspect of public life but also to reach the audience and to convince the listener to take this or that position and to gain the support of the citizens (Malina 2011). Nowadays, the success of a politician depends on his ability to master mechanisms of political communication. Political discourse aims to influence (Sheygal 20oo). The system of binary opposition is the basis of political language. The dual system is a necessary condition of democratic society: the system of pro and con argumentation, agree and criticize. One of the elements of such a dual system is intensity too. The important characteristic instrument of political speech is the intensification of some facts, positions.

The political phraseological intensifiers (PI henceforth), analyzed in this paper, are no exception. In these examples, PI are analyzed both from cognitive and pragmatic points of view, creating the convincing and persuasive impact of political affairs. Analyzing several political PU within the framework of cognitive \& pragmatic aspects, the paper attempts to shed some light on the role of $\mathrm{PI}$ in the creation of figurative and persuasive political discourse as well as how politic adaptation of PI contributes to promoting particular construal in input spaces to shape public opinions.

\section{Methodology}

As it was mentioned above, the focus of the present research is on the political discourse delivered by politicians while conducting their professional activities as well as political articles in mass media. Therefore, the data have been provided by the political articles of the influential mass media journals which served as the most accessible and largest sources for our constructed corpora and thus the best means for extracting a randomized sample for analysis.

We employed a Case study approach and comparative analysis while conducting the present qualitative study. The results of each Case have been compared to discover the best way of transferring pragmatic intentions from source (English) into target languages belonging to different language families (Russian and Uzbek).

All obtained samples of speeches and articles take place in a specific situation which can be defined in terms of basic concepts such as, purpose, setting, and participants. The purposes of the speech or article author are the communicative intentions of the author (speaker). The place or location of the situation and its participants are the features of setting along with the moment, period, when 
the speech act occurs. The aspects of the participants are the relations between them at an interpersonal or social-institutional level as well as physical indicators, social indicators, and psychological indicators.

\section{Detaching Category of Intensification}

Many scientists use in their work term "intensity". But there is no unambiguous interpretation of "intensity". Therefore, there is no clear definition of the given category. Consequently, there is no united view regarding the necessity and methods of distinguishing the following linguistic notions: intensity, expressiveness, emotionality, evaluation. Some of the scholars suppose that intensity is synonymous with expressiveness. Despite the research debates mentioned notions have received the status of independent categories.

Expressiveness and emotionality are characteristic features of PU. The category of expressiveness relates to imagination while emotionality is linked to feelings. From the functional point of view, they are differing. Expressiveness is the ability of PU to express notions brightly, colorfully, evidently, while emotionality refers to the ability to express different emotions and feelings.

On the other hand, if PU denotes a positive or negative attitude of the speaker, they convey not only expressiveness and emotionality in their meaning but also evaluation. In political texts emotionally colored units almost always have evaluation focus (Zubov 1974). We cannot claim absolutely that evaluating PU always emotional but they constantly expressive (Berlizon 1972).

Confirming the category of intensity link to related subjective categories, a great number of scientists suggest that intensity acts as a characteristic of expressivity. So, according to I.I. Turansky, "intensity is a measure of one or another strength, measure of expressivity, its degree, the measure of emotionality" (Turanskiy 1991).

The category of intensity is represented by semantic category, the essence of which lies in the expression of attribute manifestation degree as well as in logic allocation, accentuation of separate parts of the utterance.

Intensity as onomasiological category specifies quality degree, the measure of quantity, in other words, names objective quantitative certainty of this or that attribute (Turanskiy 1991). In this paper, which is carried out from the perspective of discourse researcher, the category of intensity is understood as a semantic category expressing the degree of cumulative illocutive power and the degree of expressed intentionality of its participants.

Intensification is a quantitative feature of an attribute which in its initial stage may not include evaluation and emotionality but the communicative aim of the speaker creates further subjective development of the concrete situation and generally entails evaluation and expression. The category of intensification may be denoted as the semantic category of pragmatic character derived, on one side from categories of quantity and quality and, on the other side, from distinctive pragmatic category - the substance of which may be reflected on the frames of cognitive linguistics with the help of notions "salience (relevance)" and "foregrounding" (Kubryakova 1996).

The main characteristic feature of intensification is the pragmatic character, which is absent in other above mentioned objective adjoining categories and so allows to distinguish between intensification and them. The participants (of the situation) subjective value of the given increase of attribute's quantity is the main condition for intensification to appear (Radionova 2004). 


\section{Intensification in Phraseology}

For the first time the question concerning intensification in phraseology was risen in Logan P. Smith's work "English Idioms", which was published in the books "Society for pure English" in 1922 and became a part of the book "Words and Idioms. Studies in the English language" in 1925. In the given work we find the first mention about PU with intensification meaning.

The PI could be considered from their origin, their structural-semantic and grammatical characteristics, modes of appearance, peculiarities of their use in modern English. The PU which expresses strong feelings facing expressive redefining and in most cases their components lose their literal meaning which results in PU with total intensification meaning (Kunin 1972).

The peculiarity of the reflection of the category of intensity in the phraseological level of the language is based on the features of the categorical properties of phraseological units, as well as on the specifics of their semantics. If the interaction of emotive and evaluative sem occurs in the composition of the connotative macroelement of the phraseological unit with the intensity element, it provides a greater speech effect of phraseological units in comparison with the corresponding lexemes and combinations.

The PI could contribute a lot to emphasizing urgent problems and to achieving politician's and journalist's communicative intention to influence the audience. Political figures may influence the emotional sphere of the potential elector's personality with the help of the PI.

\section{Cognitive and Pragmatic Approach}

The cognitive-pragmatic subparadigm of the science of the language "from the inside" is connected with linguistic cognitive science, communicative pragmatics, and the theory of discourse. Its inner base is the anthropocentric energetics of all the components of the emerging linguistic theory. Communicative anthropocentrism together with its multichannel synergetics distinguishes cognitive-pragmatic subparadigm not only from the immanence of structural linguistics, but also from the aspectual study of the language in the framework of modern approaches (linguistic cognitive science, cultural linguistics, communicative linguistics). For cognitive-pragmatic linguistics, the focus is not only on the language in the inextricable conjugation of its form and substance, but also on a higher unity - the active unity of language, speech communication and human (Figure 1). It is precisely such trinity that ensures a person to exist in the real world, to think and cognize, to create a value-semantic space around him - the epicenter of human culture and civilization (Alefirenko 2014).

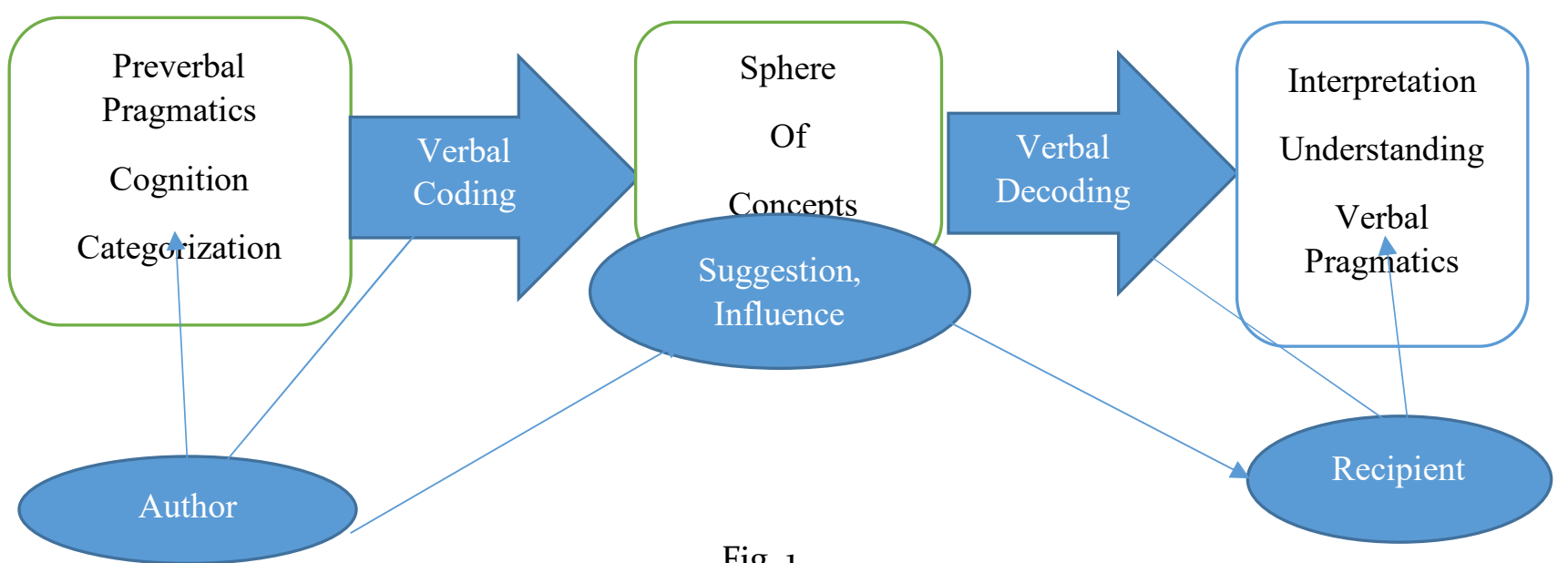

Fig. 1 
Recently, a cognitive-discursive approach, based on the inextricable unity of cognition and communication (Kubryakova 2009) and embodied in several works (Budaev et al.), acquires a new development vector related with the study of the impact on the functioning of linguistic units of social lingual factors, situational and socio-cultural context. The focus shift from cognitivediscursive research towards pragmatics allows us to talk about a separate direction of science of a language involving the study of cognitive structures as the basics of deploying discourse to achieve its strategic goals. Describing a new cognitive-pragmatic subparadigm should be noted that linguistic pragmatics, relying on cognitive linguistics, comes from the practical and communicative actions of humans. The implementation and interpretation of certain strategies of verbal communication cannot be carried out without taking into account diverse personal and sociocultural aspects of the communication process.

Consequently, the cognitive-pragmatic approach to the study of units functioning in political discourse involves the analysis of the impact of changing social, cultural, linguistic factors on mental representations of communication participants and the cognitive choice of semantic structures for communicative-pragmatic communicative formations.

\section{Cognitive and Pragmatic Aspects Applied to the PI of Political Discourse}

Political discourse should be viewed as: "A mixed product of personal development and the relevant social environment in which an individual grows. Any individual political discourse is the result of personal development in certain social settings. Personal development is affected by the individual's educational experiences, parental influence, social circles, political party, economic status, etc." (Zheng 2000)

The pragmatic and cognitive approach to PI of political discourse of the given languages could provide the basis of making the only right choice of PU of the target language (given PI) while translating into it.

\section{Case Study 1}

In the first example, the phraseological intensifier at a snail's pace (gallop) is exploited contributing to the pragmatic meaning it conveys according to the linguistic picture of the world of English native speakers.

According to Collins Cobuild dictionary of idioms, "If you say that someone does something at a snail's pace, you are emphasizing that they are doing it very slowly, usually when you think it would be better if they did it much more quickly.'

The First Known Use of snail's pace goes back to the 15th century, in the meaning defined upper (Merriam-Webster 2020). Snails are very slow creatures and it takes them a long time to reach the destination.

For instance, we took the following quotation.

'Five months before the critical gathering, Ban said talks were bogged down, and that negotiators faced many challenges and controversies. "The negotiation pace is too slow, far too slow," Ban told reporters. "It is moving at a snail's pace." (The Guardian 2015).

UN secretary-general has communicative intention to underline that debates on agreement on climate change had lasted for a very long period of time due to China's differentiated point of view on the matter. During verbal coding the author analyzed the sphere of related concepts and in order of suggestion have chosen given intensifying phraseological unit. The recipients, while decoding given PI, interpret it in accordance with their own linguistic picture of the world which is formed 
by the English linguistic picture of the world. After interpretation which may vary in accordance with recipients' personal background but still the same in general for all English language speakers, especially native, the pragmatic realization of the author's intention comes.

As mentioned above, the notions "snail" and "pace" alluded to the common past of England so generally native speakers accept it easily.

On the other hand, in Russian, we find PI “черепашьим шагом (literally, on the turtle's pace)" (Kunin 1984) that has almost the same meaning "for a very long time" as a turtle is a slow creature as a snail does. We suppose that as England is a maritime country many English PU are related to the sea so the given PI. A snail's habitat is the sea but there are many land species too. The semantic fields of the given two counterparts in English and Russian are partially coinciding.

Uzbek language offers the following PI "tuya go'shti yemoq (literally, to eat camel's meat)" which means slowing down the process.

In the given three languages (English, Russian, Uzbek) employed different zoonyms to express the same pragmatics. The peculiarity of the habitat, life, and existence of people around the world reflects in the processes of verbal cognition and later verbal coding in the native languages of these people.

Meanwhile, there is another PI "till/until the cows come home" in the English language which has a similar meaning with the upper one.

According to Collins Cobuild dictionary of idioms, 'If you say that you could do something until the cows come home, you mean that you could do it for a very long time.'

This phrase alludes to the time a herd of cows take to make their way home. Cows are very languid animals and take their own sweet time at an unhurried pace to return home. The phrase was first seen in print in 1829 , but was probably in use before that. (The Idioms 2020).

For example, in the following quotation, 'Britain's politicians should embrace clichés till the cows come home' (The Guardian 2012). The author has communicative intention to show that clichés should be used by British politics for a very long period of time due to lack of imagination of later to coin new ones. During verbal coding the author analyzed the sphere of related concepts, and in order of suggestion have chosen given intensifying phraseological unit. The readers while decoding given PI interpret it in accordance with their own linguistic picture of the world which is formed by English history, traditions, culture, way of life, and so on. After interpretation which may vary under personal background but still is the same, in general, for English native speakers, the pragmatic realization of the author's intention comes.

On the other hand, in Russian, we find PI "когда рак на горе свиснет (literally, when crab whistles on the mountain)" (Kunin 1984). It has almost the same meaning "for an unpredictably long period of time" and "never" as it is impossible for a crab to get to the mountain and to whistle too. But semantic fields of the given two counterparts in English and Russian are crossing with each other but not coincide. The English variant still employs the possibility of cow to come home while the Russian one says definitely "never". In comparison with the PI "snail's pace" the sem of later PI contains the connotation of impossibility. In the first example the needed result will be reached at least but here it may last forever.

\section{Case Study 2}

In the following example, we shed some light on the phraseological unit "crocodile tears" which was used by London mayor Sadiq Khan in his speech on London knife crime crisis, 'For the Prime 
Minister and Home Secretary to now cry crocodile tears is no consolation, we need rapid investment now.' (The Sun 2019; The world news 2019).

The phraseological unit "crocodile tears" refers to someone who shows emotions like grief, sorrow, or pity but are insincere and has a habit of being hypocritical about the situation. That means when someone cries crocodile tears, their emotions aren't real and they don't feel pity for the person they're crying for or feel sorry for their actions. (Typingadventure 2019).

Contrary to the phraseological unit, though, they don't cry because of false emotion. However, since we equate tears to emotion, in a human sense, it is confusing why a predator would cry when chomping down their prey. Hence, the idea of crocodile tears was created. Even if a crocodile looks like it is crying, they aren't really sad for their prey. It's simply a physical appearance of being sad, but not necessarily a genuine show of emotion.

At the stage of verbal coding Mayor exploits expressive and bright PU which denotes insincere display of emotions, false but we cannot find intensifying sem in it. It conveys only expressive impact. There is no degree of expressive measure which is needed for intensification to appear as we assumed previously.

The PU with the same meaning could be found in Russian language, 'крокодиловы слезы (literally, crocodile tears).' Here we observe the total coincidence of the given concept in both languages.

On the contrary we cannot find the same usage of the notion "crocodile" in the Uzbek language. The given idiom is translated in Uzbek as 'yolg'on yig'i; shayton yig' (literally false tears)' which corresponds to free translation.

\section{Case Study 3}

In the third example, we have a look at the PI "to live/be in clover" to unveil pragmatic meaning it suggests in the linguistic picture of the world of English native speakers.

As stated in Collins Cobuild Dictionary of Idioms, 'If you are in clover, you are happy or secure because you have a lot of money or are enjoying a luxurious lifestyle'. In Macmillan Dictionary we find, 'enjoying a pleasant comfortable life, usually because you have a lot of money'.

This PI, with its analogy to cattle feeding happily in a field of clover, dates from the early eighteenth century. It used as "like pigs in clover" too. In the twentieth-century America we find "rolling in clover". But the pragmatic meaning of the listed PI is "to live very well." (Christine 2013).

For instance, in the following quotation, 'Cameron still in clover' (The Guardian 2006). The journalist has communicative intention to show that ex-prime minister of the United Kingdom David Cameron has a comfortable life. During verbal coding the journalist analyzed the sphere of related concepts and in order of suggestion choose given intensifying phraseological unit. The readers while decoding given PI interpret it following their linguistic picture of the world which is formed by English environment as well as political position. After interpretation which may vary according to political views and background of the reader, correct pragmatic realization of the author's intention would appear.

We know, the concept "clover" alluded to the common past of England with positive connotation so generally native speakers interpret it at ease.

On the other hand, in Russian, we find PI "как сыр в масле кататься (literally, as cheese slides in butter)" (Kunin 1984). which has almost the same meaning "living in luxury, prosper, very well". Russians employ "cheese" and "butter" notions to express the same meaning. 
Uzbek language offers the following PI "pichog'i moy ustida (literally, knife over butter)" which means "to be in a comfortable environment, very well". The peculiarity of the habitat, life, and existence of the people reflects in the processes of verbal cognition and later verbal coding of the speaker.

So semantic fields of the given two counterparts in Russian and Uzbek are crossing with each other but not coincide. The English variant differs from Russian and Uzbek counterparts.

\section{Conclusion}

In other words, political discourse is one of the distinct and emotionally marked types of discourse where pragmatic potential can be realized by the means of PI.

Cognitive surveys discover (unfold) discursive conditioning and the role of PU in the objectification of information field of a linguistic personality (Feoktistova 2009; Chernikova 2015) thereby revealing their functional potential. The cognitive and pragmatic subparadigm of phraseology considers "a phrase character in its two following forms: linguistic and discursive" (Alefirenko 2008), allowing us to discover cognitively-pragmatic functions of phraseological units in a particular discourse and reveal cognitive-pragmatic potential of this character of indirectly derived nomination.

Identification and preservation of pragmatical potential of the PI of English political texts and their cognitive function could contribute to adequate transfer of authors (politics) communicative intention while translating to Russian and Uzbek languages. The main cognitive functions of PI are determined in the frames of given pragmatic parameters of political discourse is to reach the appropriate communicative impact of the translated text in recipients' language too. Decoding of PI is a cognitive process, the implementation of which depends on the ability of the recipient to interpret the utterance in the coordinates of the intentionality of the producer. Pragmatic aims of the speaker in the given context could be summed up as the pursuit to draw in the recipient's mind the figure of pseudo-reality for a more effective compulsion of his or her statements.

The problem lay at the appropriate transfer of political PI to the target text so that to preserve the pragmatic potential of original political text and to influence. We can say that pragmatic aims are reached while the proper counterpart of English PI in Russian and Uzbek languages is found which is not always possible. Therefore, in such cases, unless the right counterpart of the target language is found, it is better to employ free translation/interpretation to avoid misunderstandings.

\section{References}

Abramyan S.A. (2016). Angloyazychnyy politicheskiy diskurs v mezhkul'turnom kontekste. -Yer., Izd-vo YEGU. - $534 \mathrm{~s}$.

Alefirenko N.F. (2008). Frazeologija v svete sovremennyh lingvisticheskih paradigm. M.: JeLPIS. (In Russ.).

Alefirenko N.F. (2014). Kognitivno-pragmaticheskaja subparadigma nauki o jazyke. Kognitivnopragmaticheskie vektory sovremennogo jazykoznanija: sb. nauch. tr. M. 16-27. (In Russ.).

Anderwald, L. (2016). I'm loving it-Marketing ploy or language change in progress? Studia Neophilologica. https ://doi.org/10.108o/o0393 274.2016.1208536.

Bagga-Gupta, Sangeeta. (2014). Languaging: Ways-of-being-with-words across Disciplinary Boundaries and Empirical Sites. In Language Contacts at the Crossroads of Disciplines, ed. Heli Paulasto, Lea Meriläinen, Helka Riionheimo, and Maria Kok, 89-13o. Newcastle-upon-Tyne: Cambridge Scholars Publishing. 
Bagga-Gupta, Sangeeta. (2018). Learning Languaging Matters. Contributions to a Turn-on-Turn Reflexivity. In Reconceptulizing Conceptions between Language, Learning and Literacy, ed. Sangeeta Bagga-Gupta, Anne Golden, Lars Holm, Helle Laursen, and Anne Pitkänen-Huhta. Rotterdam: Springer.

Baker, M. (2010). In Other Words, (London: Routledge).

Bali, Aasita and Jagan, Shivani. (2017). Use of Social Media in India and Political Communication. International Journal of Humanities and Social Science Studies IJHSSS, 243-253. http://oaji.net/articles/2017/1115-1486537686.pdf.

Bell, D.V.J. (1975) Power, Influence and Authority: An Essay in Political Linguistics. London: Oxford University Press.

Bell R.T. (1991). Translation and Translating: Theory and Practice, (London: Longman).

Berlizon S.B. (1972). Virajeniye ekspressivnosti i emocionalnosti v frazeologicheskih edinicah i slove. Voprosi frazeologii. Trudi Sam.GU im. Navoi, novaya seriya. Vip.219. Samarkand. 242. (In Russ.).

Blommaert, (2015). Commentary: Superdiversity Old and New. Language \& Communication. https://doi.org/10.1016/j.langcom.2015.01.003.

British Newspaper Archive. (2020). Available at: www.britishnespaperarchive.co.uk.

Budaev, E. V., Chudinov, A. P. (2008). Kognitivno-diskursivnyy analiz metafory v politicheskoy kommunikatsii. Politicheskaya lingvistika, 3 (26): 37-48. (In Russ.).

Carter, R., \& McCarthy, M. (2017). Spoken grammar: Where are we and where are we going? Applied Linguistics, 38(1), 1-20. https ://doi.org/10.1093/appli n/amuo8 o.

Chernikova A.Je. (2015). Problemy kognitivnogo modelirovanija vo frazeologii. Kognitivnye issledovanija jazyka. 21. 525-527. (In Russ.).

Chomsky, Noam. (2003). Power and terror, (New York : Seven Stories).

Christine A. (2013). The Dictionary of Clichés.

Ciprianová, E. (2009). "Metaphor in Translation”, Topics in Linguistics, 4, (Slovakia: Constantine the Philosopher University), pp. 12-16.

Collins Cobuild. (2012). Idioms Dictionary (Collins Cobuild). Third Edition HarperCollins UK. 320

Cowie, A. (2007). Oxford Dictionary of Current Idiomatic English. Oxford: Oxford University Press.

Cowie A., Mackin R. - Mc. Caig, I. (1994). Oxford Dictionary of English Idioms, Oxford: Oxford University Press. ISBN-13: 978-0-19-431287-5. ISBN: 0-19-431287-9. 686.

Davletbaeva D. - Yarmakeev I. (2014). Lexicographic Presentation of Phraseological Transforms. In E. ARSENTEVA (ed) Phraseology in Multilingual Society. Cambridge: Cambridge Scholars Publishing. 329 $-338$.

Feoktistova A.B. (2009). Rassmotrenie problem semantiki idiom s pozicij kognitologii. Rema. Rema. 4. 8693. (In Russ.).

Jacobsen, N. (2015). A Cognitive Linguistic Analysis of English Conditionals in English for Special Purposes (EAP) Instruction: Implications from Sociocultural Theory. In K. Masuda, C. Arnett, \& A. Labarca (Eds.), Cognitive Linguistics and Sociocultural Theory, 103-126. Berlin: Mouton de Gruyter.

Johansson F.M. \& Gibbs, R. W. (2012). Embodied Motivations for Metaphorical Meanings. Cognitive Linguistics, 23, 251-272.

Johansson M. (2006). Constructing objects of discourse in the broadcast political interview. Journal of Pragmatics, 38 (2), 216-229. https://doi.org/10.1016/j.pragma.2005.06.016.

Kehler, A. (2002). Coherence, reference, and the theory of grammar. Stanford: CSLI. 
Kibrik, A. A. (1994). Kognitivnye issledovaniya po diskursu. Voprosy yazykoznaniya, 5: 126—139. (In Russ.).

Kohl-Dietrich, D., Juchem-Grundmann, C., \& Schnotz, W. (2016). Conceptual Motivation as a Tool for Raising Language Awareness in the English as a Foreign Language Classroom - Does It Enhance Learning Outcomes? Insights from an Empirical Study. In J. Goschler, \& S. Niemeier (Eds.), Yearbook of the German Cognitive Linguistics Association, 4, 193-209.

Komissarov V.N. (1998). Theory of translation (linguistic aspects). M.

Kubryakova E. S. (2009). V poiskakh sushchnosti yazyka. Voprosy kognitivnoy ingvistiki. 1. 5-13. (In Russ.).

Kubryakova Ye.S. i dr. (1996). Kratkiy slovar' kognitivnykh terminov. M. 21-25. (In Russ.).

Kubryakova, E. S. (2004). Yazyk i znanie: na puti polucheniya znaniy o yazyke: chasti rechi s kognitivnoy tochki zreniya: rol' yazyka v poznanii mira. Moskva: Yazyki slavyanskoy kul'tury. (In Russ.).

Kunin A.V. (1972). Frazeologiya anglijskogo yazyka. Moskva. Mezhdunarodnye otnosheniya. ISBN o46894. 288. (In Russ.).

Kunin A.V. (1984). English-Russian Phraseological Dictionary. 20,0oo idioms approx. 4th edition, revised and enlarged, with bookmarks. - Moscow: Russkiy Yazyk.

Lascarides, A., \& Stone, M. (2009). A formal semantics of gesture. Journal of Semantics, 26(4), 393-449.

Lee, J. J., \& Deakin, L. (2016). Interactions in L1 and L2 Undergraduate Student Writing: Interactional Metadiscourse in Successful and Less-successful Argumentative Essays. Journal of Second Language Writing, 33, 21-34

Levinson, S. (1983). Pragmatics. Cambridge: Cambridge University Press.

Logan P. Smith (1925). Words and Idioms. Studies in the English language.

Long, T.H., D. Summers, C. Boyle (eds). (1992). Longman Dictionary of EnglishIdioms. Fourth edition, London: Longman.

Macmillan Dictionary. (2020). https://www.macmillandictionary.com/

Malina A. D.(2011). Politicheskaya ritorika: Lingvisticheskiye strategii argumentirovannogo diskursa v sovremennom angliyskom yazyke (na mat. publichnykh vystupleniy) [Elektronnyy resurs]. URL: http://rae.ru/forum2o11/18/1582

Merriam-webster (2020). Dictionary. https://www.merriamwebster.com/dictionary/at\%20a\%2osnail\%27s\%2opace.

Mount, A. (2008). Intentions, gestures, and salience in ordinary and deferred demonstrative reference. Mind and Language, 23(2), 145-164.

Niemeier, S. (2017). Task-based Grammar Teaching of English - Where Cognitive Grammar and Task-based Language Teaching Meet. Tübingen: Narr.

Nowak, E., \& Michaelson, E. (2019a). Meta-metasemantics, or the quest for the one true metasemantics. (Manuscript).

Nunberg, G. (1995). Transfers of meaning. Journal of Semantics, 12(2), 109-132.

Ornatowski, C.M. (2012). "The Idea of Politics in 'Political' Rhetoric" Forum Artis Rhetoricae, 2/2012, 7-21.

Pishkova E. Yu. (2016). On the Issue of Translation of Evaluative Vocabulary in the Political Discourse. ISSN 1997-2911. № 10 (64). Ч. 2

Pridham, G. (2005). "Designing Democracy: EU Enlargement and Regime Change in Post-Communist Europe”, (Basingstoke: Palgrave Macmillan). 261-284. 
Radionova S.Ye. (2004). Intensivnost' i yeyo mesto v ryadu drugikh semanticheskikh kategoriy. Slavyanskiy vestnik. 2. M. MAKS Press. 303-308. (In Russ.).

Rosch, Eleanor. (1975). Cognitive representations of semantic categories. Journal of Experimental Psychology: General 104 (3): 192-233.

Runciman D (2007) The paradox of political representation. J Polit Philos 15(1):93-114

Sapir, E. (1949). Selected Writings in Language, Culture and Personality. LosAngeles: University of California Press.

Schäffner, C. (1997). "Strategies of Translating Political Texts", in Text Typology and Translation, Anna Trosborg (ed), (John Benjamins). 119-145.

Schäffner, C. and Bassnett, S. (2010). Political discourse, media and translation. Newcastle : Cambridge Scholars.

Sheygal Ye. I. (200o). Semiotika politicheskogo diskursa: diss. ... d. filol. n. Volgograd. 431 s.

Sheygal, Ye.I. (1990). Intensivnost' kak komponent semantiki slova v sovremennom angliyskom yazyke [Tekst]: diss. ... kand. filol. nauk / Ye.I. Sheygal. - M.

Speaks, J. (2016). Speaker and hearer in the character of demonstratives. Mind, 125(498), 301-399.

Stojni'c, U., Stone, M., \& Lepore, E. (2017). Discourse and logical form: Pronouns, attention, and coherence. Linguistics and Philosophy, 40(5), 519-547.

Stone J, Fernandez N (2008) To practice what we preach: the use of hypocrisy and cognitive dissonance to motivate behavior change. Soc Personal Psychol Compass 2(2):1024-1051

TELIYA, V. (1999). Frazeologiya v kontekste kul'tury. In Pervoocherednye zadachi i metodologicheskie problemy issledovaniya frazeologicheskogo sostava yazyka v kontekste kul'tury, p. 336. Moskva: Yazyki russkoj kul'tury. ISBN 5-88766-o61-9. (In Russ.).

The Guardian. (2006). https://www.theguardian.com/news/blog/2006/apr/o6/cameronstilli)

The Guardian. (2012). https://www.theguardian.com/commentisfree/2012/mar/12/britain-politicianscliches)

The Guardian. (2015). https://www.theguardian.com/environment/2015/jun/29/un-climate-talks-movingat-snails-pace-says-ban-ki-moon\#maincontent.

The Idioms. (2020). https://www.theidioms.com/until-the-cows-come-home/).

The Sun. (2019). https://www.thesun.co.uk/news/5968714/sadiq-khan-london-mayor-resign-wife-born/

The world news. (2019). https://theworldnews.net/gb-news/sadiq-khan-flies-back-from-his-holiday-toblame-the-government-for-london-knife-crime-epidemic-on-his-watch/

Tsurikova, L. V. (2003). Novye aspekty izucheniya diskursa: adekvatnost' diskursivnoy deyatel'nosti kak kommunikativno-kognitivnyy fenomen. Na styke paradigm lingvisticheskogo znaniya v nachale XXI: gram-matika, semantika, slovoobrazovanie. Kaliningrad: Izd-vo KGU. 175-186. (In Russ.).

Turanskiy I.I. (1990). Semanticheskaya kategoriya intensivnosti v angliyskom yazyke. Monografiya. M.: Vysshaya shkola.173. (In Russ.).

Turanskiy I.I. (1991). Soderjaniye i virajeniye intensivnosti v angliyskom yazike. Dis...dok.filol.nauk. M. 6-7. (In Russ.).

Typingadventure. (2019). https://www.typingadventure.com/crocodile-tears-meaning/)

Wierzbicka, Anna. (1991). Cross-cultural pragamtics: the semantics of human interaction.NewYork:de Gruyter. 
Zheng, Tongtao. (2000). Characteristics of Australian Political Language. Rhetoric:Tactics of gaining public support and shirking responsibility.

Zubov A.V. (1974). O yazikovih sredstvah virajeniya kategorii ocenki v sovremennom angliyskom yazike (na materiale anglo-amerikanskoy pressi). AKD. M. 7. (In Russ.). 